\title{
Development of discurcive power strategies in political space of Dnipro
}

\author{
Nadiya Mikhno, Oles Honchar Dnipro National University
}

The article deals with defining the characteristics of the authority discourse development in modern society. The localization of the urban area has been chosen as the field of the authority discursive power strategies development. The author's scheme of authority discourse analysis in the urban area has been suggested basing on the methodological principles of a discourse-analytical strategy and involving the heuristic potential of a socio-cultural and semiotic analysis, as a result of the specific empirical study. The analysis of theoretical frames for the study of the concepts of «discourse» and «authority» has made it possible to determine a variety of communicative actions, which subject can only be the authority - an institutional discourse, namely, a political perspective.

It is proposed to define a political discourse as a set of all speech acts in the appropriate institutional atmosphere, which is implemented in both oral and written forms within this study. The consideration of the background, expectations of the author and the audience, hidden motives, plot schemes etc. are provided in this article. It has been noted that it is appropriate to use the categorization approach to the «soft power» concept, which proposes to consider the power as the one which is implemented in the form of a certain communicative action. The behavior dictated by the authorities is perceived by a recipient as a voluntary choice during its relization. Such categories of the investigation as cultural mechanisms of nomination, classification, legitimation and naturalization are stressed analysing a political discourse in an urban area. The author's matrix of the analysis of the authority discourse in the urban area which includes its strategies, grammatology, idioms and the nature of their projection in discursive strategies of main subjects of discourse development has been described.

Keywords: city, urban area, authority discursive strategies, institutional discourse, political discourse, discourse of power, power of discourse

\section{Виробництво дискурсивних стратегій влади в політичному просторі м. Дніпро Надія Міхно, Дніпровський національний університет імені Олеся Гончара}

Основна увага в даній статті зосереджена на визначенні характеру виробництва дискурсу політичної влади в умовах розвитку сучасного суспільства. В якості поля розгортання дискурсивних стратегій влади було обрано локалізацію міського простору. Спираючись на методологічні принципи дискурс-аналітичної стратегії та залучаючи евристичний потенціал соціокультурного та семіотичного аналізу, у результаті конкретного емпіричного дослідження було запропоновано авторську схему аналізу дискурсу влади в міському просторі. Здійснений аналіз теоретичних фреймів вивчення концептів «дискурс» та «влада» дозволив визначити різновид комунікативних дій, суб'єктом якого може бути лише влада, - інституційний дискурс, зокрема, політичний ракурс. Запропоновано в межах даного дослідження сприймати політичний дискурс як сукупність усіх мовленнєвих актів у відповідній інституційній атмосфері, що реалізується в усній та писемній формах, передбачає врахування фону, очікувань автора та аудиторії, прихованих мотивів, сюжетних схем тощо. Відзначено, що доцільно використовувати підхід до аналізу влади в категоріях концепції «м'якої влади», що пропонує розглядати владу як реалізовану в формі певної комунікативної дії, у процесі якої поведінка, що диктується владою, сприймається реципієнтом як добровільний вибір. Окрема увага в ході аналізу політичного дискурсу в міському просторі приділена таким категоріям аналізу, як культурні механізми номінації, класифікації, легітимації та натуралізації. Запропоновано авторську матрицю аналізу владного дискурсу в міському просторі, що передбачає звернення уваги на стратегії владного дискурсу, граматологію владного дискурсу, інтеціональність владного дискурсу, ідіоми владного дискурсу та характер їх проекції в дискурсивних стратегіях основних суб'єктів виробництва дискурсу влади в міському просторі.

Ключові слова: місто, міський простір, дискурсивні стратегї влади, інституціийний дискурс, політичний дискурс, дискурс влади, влада дискурсу 


\title{
Производство дискурсивных стратегий власти в политическом пространстве г. Днепр
}

\author{
Надежда Михно, Днепровский национальный университет имени Олеся Гончара
}

Основное внимание в данной статье сосредоточено на определении характера производства дискурса политической власти в условиях развития современного общества. В качестве поля развертывания дискурсивных стратегий власти было избрано локализацию городского пространства. Опираясь на методологические принципы дискурс-аналитической стратегии и привлекая эвристический потенциал социокультурного и семиотического анализа, в результате конкретного эмпирического исследования было предложено авторскую схему анализа дискурса власти в городском пространстве. Осуществленный анализ теоретических фреймов изучения концептов «дискурс» и «власть» позволил определить разновидность коммуникативных действий, субъектом которого может быть лишь власть, - институциональный дискурс, в частности, политический ракурс. Предложено в рамках данного исследования воспринимать политический дискурс как совокупность всех речевых актов в соответствующей институциональной атмосфере, что реализуется в устной и письменной формах, предполагает учет фона, ожиданий автора и аудитории, скрытых мотивов, сюжетных схем и тому подобное. Отмечено, что целесообразно использовать подход к анализу власти в категориях концепции «мягкой власти», что предлагает рассматривать власть как реализованную в форме определенного коммуникативного воздействия, в процессе которого поведение диктуется властью, воспринимается реципиентом как добровольный выбор. Отдельное внимание в ходе анализа политического дискурса в городском пространстве уделено таким категориям анализа, как культурные механизмы номинации, классификации, легитимации и натурализации. Предложено авторскую матрицу анализа властного дискурса в городском пространстве, что предполагает обращение внимания на стратегии властного дискурса, грамматологию властного дискурса, интенциональность властного дискурса, идиомы властного дискурса и характер их проекции в дискурсивных стратегиях основных субъектов производства дискурса власти в городском пространстве.

Ключевые слова: город, городское пространство, дискурсивные стратегии власти, институциональный дискурс, политический дискурс, дискурс власти, власть дискурса

$\mathrm{I}$ $\mathrm{n}$ the conditions of existence and development of modern society, with authority institutions' constant increase of influence on the processes of daily life on the agenda of the scientific community, the problem of researching the organization character of power agents' discursive strategies development field is increasingly emerging. An important issue, which is the researchers' interest in the authority relation discursive field of power relations, appears only at that moment when the main conditions for exercising power through discourse is the control of the discourse itself and the control of its development.

Power groups and their representatives control or have access to a wide range of discursive roles, genres and styles. Thus, media corporations, and often their executives, control both the financial and technological conditions of discourse, such as the press, television, the publishing business, the telecommunications and computer industries. The way in which articulation is produced is controlled by groups that refer to the term «symbolic elites» in the information age. Journalists, writers, artists, scholars, who exercise power on the basis of «symbolic capital» refer to «symbolic elites». However, they have comparative freedom in choosing discourse genres and style of discourse presentation because most elite groups are governed by the state or private corporations. Therefore, their articulation freedom is also limited [6].

Authority discourse unfolds at different levels of social life - from the macro level of the country to the local level of urban communities. In this article, we propose to consider the exact way of discursive power strategies development (namely political one) which occurs at the level of the urban area. The most important thesis of our study is the fixation of the fact that the subject of the study is the semiotics of the urban area in the structuralist and post-structuralist paradigm, which are basic for the analysis of discourse - the «text of the city».

Thus, the city as a text exists in two forms. Firstly, the integral image of the city, expressed by its cultural and historical features, is historically formed. As for A. Lefebvre [1], this image can be called «iconic», while it is necessary to emphasize that the concept of «iconic» image should be 
considered widely. An example of an iconic image of a city is its official image. Secondly, the city as a text exists in a form of many socio-semantic situations which are variants of interpretation by the subjects of perception of the urban area as a whole and as its individual fragments. They are texts of urban communities that arise in the course of everyday practices of living and experiencing the urban area and the consumption of authority discourse subjects' discoursive strategies.

Representatives of different scientific fields such as linguistic, political, sociological ones etc., were engaged in the study of authority discourse development peculiarities. In particular, such recognized theorists as T. Adorno, R. Bart, J. Baudrillard, R. Vodak, T. van Dijk, N. Luman, G. Marcuse, P. Ricker, M. Foucault and others who offered basic methodological orientations for the study of the authority nature and the nature of its discourse development of (re)presentation focused their attention on the authority discourse.

The purpose of this article is to define the theoretical frame for authority discourse analysis and their explication in a practical case of studying discourse strategies in the urban area (the city of Dnipro as an example).

D. Shapochkin, agreeing with V. Chernyavskaya [2], noted very clearly in his publications that the meaningful definition of the "authority discourse» concept: the discourse of power is a systematic and orderly use of language, which traces a particular ideological and socially determined mentality specifically purposeful ways such as a way of thinking and a way of communicative-linguistic practices that are connected with the exercise of social power. Discourse is an expression of power, and power is expressed in discourse through the system of interrelated linguistic / textual means, forms and methods of action [3].

We suppose that heuristically interesting ideas have been proposed by the sociolinguist V. Karasik [4]. He distinguishes between personal (individual-oriented) and institutional (statusoriented) discourse. The first one means that the subject of discourse acts as a personality with its rich inner world while the second one identifies the subject of discourse acts as a representative of a particular social group.

Personal discourse has two types: domestic and life communication. Communication occurs within certain limits of status-role relations in the institutional discourse and it is distinguished on the basis of two characteristics: the purpose and participants of communication. Such discourses as: political, diplomatic, administrative, legal, military, pedagogical, religious, mystical, medical, business, advertising, sports, scientific, stage and mass information are distinguished in the structure of institutional discourse, respectively. These types of institutional discourse are characterized by the use of communicative strategies of influence and provide an analysis of the authorities' relations in these discourses [5].

These preliminary observations have led us to the need (current relevance) to cover the frames of authority discourse analysis more clearly within our study. This way we completely agree with the opinion of V. Sogomonyan [7] who follows the view point of the French School of Discourse Analysis representatives and denotes the perspective for discourse analysis identification of the discourse subject in order to be able to ascertain the institutional indispensability of this subject for this type of discourse (discursive formation). In other words, it is important to register that type of communicative actions which subject is authority. In this case, V. Sogomonyan [7] notes that the foreshortened perspective should be political, as certain characteristics of the power institute indicate such a characteristic, which implies the mandatory implementation of a number of communicative acts by the authorities provided that these communicative acts can be performed only by authority (or its authorized representatives).

As a result, it should be noted that in the future, a specific case study will focus on the analysis of political discourse as a form of authority discourse.

Since discourse is a type of communication oriented to discussion, justification, agreement of its participants' views, when communication paricipants become authority representatives or claim to do it, the discourse becomes political. The most significant tasks to be resolved during the political discourse are: the implementation of a free, voluntary expert examination of the current political course and emerging public problems; designing alternative projects for future development, ways and means of progressive democratic development of society. The initiators of political discourse are the ruling elite of the national, regional, local level, as well as existing and emerging structures of civil society.

Thus, political discourse is understood as 
speech formations (a coherent (oral or written) text) concerning the policy scope, implemented verbally and non-verbally, actualized in a specific situational context, intended to serve a political communication sphere. The systematic characteristics of political discourse include mass character, the dominance of emotionality, the use of manipulation, the mediation of political communication by the factor of media (publicity of politics), theatricality, the dynamics of political language, which is determined by the relevance of the reflected events and political situation changeability.

The allocation of political discourse as a separate concept follows from the understanding of politics as a particular sphere of social life, connected with the phenomenon of power, which permeates all spheres and levels of social interaction [8]. Therefore, political discourse can be defined as a set of all speech acts in the appropriate institutional atmosphere [9], which is implemented in both oral and written forms, assuming the background, the author's and audience's expectations, hidden motives, plot schemes and so on [10].

In today's scientific sphere, the concept of «political discourse» is viewed from different angles. Firstly, political discourse is understood to mean texts that reflect the political and ideological practices of a particular country, party, political trend in a particular era, and social consciousness. The basis of political discourse is the nomination of facts and the following comments. It reflects the political situation, sets possible forms of political practice. Secondly, political discourse is the result and the effectiveness of communication. The purpose of political discourse is not to describe but to convince the recipients' intention, to encourage «politically correct» actions or assessments. This is «a kind of theatrical aggression». Moreover, political discourse is seen as a manifestation of personal authorial meanings in certain circumstances [10].

The postmodern interpretation of political power focuses on today's world use of «soft power» as the most effective one. Unlike «hard power», soft power is not perceived as a force that acts from the outside. "Soft power» is a power which is realized in the form of a certain communicative action, in the course of which the behavior dictated by the authorities is perceived by the recipient as a voluntary choice. Discursive management of the symbolic space of politics is the primary purpose of «soft power» policy and practice. Such discourse allows to influence the mental structures of the mass consciousness such as public perceptions, dreams, ideals, hobbies, etc without using pressure and compulsion [6]. As for this context, the theory of «language games» is represented as a tool for analyzing political discourse. A specific concept of political linguistic games emerges basing on the general concept of language game in political linguistics and discourse analysis. It should be understood as a link between the political text and its context where a political subject, carrying a specific message to addressee, adheres to a specific verbal behavior.

It should be noted separately that political discourse can be presented either orally or in a written form. The oral form is implemented by such forms as public speaking by high-ranking politicians, their interviews, radio and television appearances, press conferences, parliamentary debates, political news in television and radio broadcasts. The oral form of political discourse is personal because it is followed by individuality. The argumentation in this case is accepted in the unity of verbal, non-verbal and extralinguistic. In turn, the written form covers not only extensive documentation (treaties, agreements, protocols), but also the press (sections reserved for political facts) and political advertising (mainly posters) [11].

In particular, the analysis of political discourse in urban space provides appeal to such categories of analysis as cultural mechanisms of nomination, classification, legitimation and naturalization. According to P. Bourdieu [12], nomination and classification are functions and attributes of legitimate authority. Nomination is the naming or definition of any social objects, phenomena, groups, and individuals; classification is their reference to certain types, classes. Nomination and classification are realized by any social agent and are recognized within its influence. Another cultural mechanism of power is legitimation, which can be viewed through the leading role of rituals. According to P. Berger and T. Lukman [13], legitimation is the second-order semantic objectification, in other words, the creation of values that must explain and justify the content and form of the institutional system.

Another cultural mechanism of power is naturalization. Yu. Soroka [14] notes in the study of culture and power connection that naturalization 
as a cultural mechanism can be analyzed with the help of R. Barthes' semiotic perspective on the study of the myth: myth is a semiological system consisting of a signified (concept), a signifier (acoustic image) and a sign (associations of the two previous ones), such as language. Although, myth is a secondary semiological system, its signifier is formed of language signs. Myth is a meta-language, secondary language spoken of first. The material carriers of myth (or a mythical message) are not only the language itself, but also photography, painting, advertising, objects or actions of people (including rituals). This happens when the objects listed become signs. They are perceived as a part of a particular message, not according to their own place and function. Social naturalization practices are represented in the ways of cultural traditional creation and reproduction through the support of appropriate symbols, rituals and myths.

Following a number of researchers in the specifics of political discourse, it should be noted that political text in institutional political discourse is an instrument of power that can transform language and communication mechanisms into a source of power. Moreover, G. Girnth imposes an idea of the primary (about the object) and secondary text (meta-text) in the political sphere. The original text may be the party's conclusion, resolution, order, law, that is, such text that informs of a significant decision. It becomes the object of a meta-text, i.e. news, analytics, comments on this decision. In this context, S. Kryvenko [15] notes that R. Bart states that meta-language is provided with such features that make it mythological. Conditional sentences, imperative mood and even expressiveness can be the ground for various manipulations by means of political texts. According to the importance of meta-language texts for political discourse, it can be distinguished such types of a meta-text: discursive-transcendental (which can be attributed to more than one discourse): in particular, political pre-election discourse should be considered as a combination sphere of agitation, information, historical, journalistic, ritual and other texts; discursive-immanent (belonging to only one discourse); discursive-peripheral (more important and less significant texts); discursivedominant; meta-discursive (texts giving topicality of discourse and its functioning).

We also propose to pay attention to a causalgenetic approach to the study of the content of texts in the course of their functioning in the real social environment in the context of the study of the political practices of articulation. This approach allows projecting text into a discursive sphere, which makes it possible to identify all sorts of contexts «entered» in the text and to reconstruct them from a single, multilayered, multidimensional textual content. J. Chalaby [16] notes that as N. Phillips and S. Hardy point out, discourses are realized through different texts, although they exist outside the specific texts that form them. Thus, texts can be regarded as a discourse «unity» and material embodiments of discourse.

And as we noted earlier, texts can take many forms, including written texts, oral words, images, symbols, artifacts, etc. The body of texts produced by the subjects of urban political discourse, represented by three main groups: public speeches (appeals) of officials of local self-government, public speeches of representatives of opposition groups, the rhetoric of the expert community (political experts, community activists, etc.), has been chosen as the object of analysis.

It should be noted separately that the discourse is objectively characterized by such systemforming features as the status qualification of its participants; localized chronotope; conventionally defined in the framework of this social institute goal; ritually fixed values; intentionally defined strategies (sequence of speech actions in typical situations), etc. [17].

We haverelied on certain provisions of E. Laclau and Ch. Mouffe, Y. Lotman's poststructuralist theory of discourse regarding the processes of social-communicative function of the text and we have taken into account $T$. van Dijk's position of extralinguistic factors of text formation in the course of the author's research.

During the author's study, we relied on the theory of discourse by E. Laclau and Ch. Mouffe. We are interested in author's original theses on the interpretation of discourse and the proposed methods of its analysis. Within their theory, discourses are seen as ways of communicating and understanding the social world, competing with one another to give the social world certain meanings. Discourses are constantly involved in the struggle for domination. The purpose of discourse analysis, according to Laclau and Mouffe, is to outline the processes of structuring social reality, during which the attachment of certain signs to certain values, establish, reproduce and change the relationship of identity. These processes are 
called Laclau and Mouffe term «articulation». Discourse is understood as an unfinished, open to change structure, as a multivariate range of articulations, as a conglomerate, in which, in addition to the fixed value, there are always other potential variants of values that can transform the structure of discourse. Discourse structure changes by analyzing articulations that constantly conduct, challenge, and redefine the structural components of discourse. An important point is that Laclau and Mouffe are prepared to include all social practices in the field of discursive analysis, since they do not distinguish any non-discursive social practices.

An important point to our analysis is that Laclau and Mouffe's [18] discourse theory places great emphasis on policy analysis. In fact, they interweave politics with discursive practices because it is a way of constructing, reproducing and transforming the social world. Actually, all politics is seen as a sphere of struggle between certain discourses. Political articulation defines how we act and think, representing a way of ruling and distributing power. The authorities can mobilize people for active action by creating values.

We are interested in three levels of research concerning the potential of linguistic-semiotic analysis. These levels are the signs themselves and the sign structures; codes and systems that organize sign communications; the cultural context for their interaction. Semiotics integrates with the conceptual arsenal of structuralism, studying information and communication processes as linguistic structures and systems of the linguocultural continuum. Thus, we perceive political texts as holistic semiotic forms of linguistic psychosocial activity of a speaker, conceptually and structurally integrated, serving as a pragmatic mediator of communication and dialogically embedded in the semiotic universe of culture.

Continuing the logic and problematics we have laid out above, we propose to pay attention to the body of political texts of the subjects of power discourse in the city (the city of Dnipro as an example) to analyze the peculiarities of the discourse strategies of the authorities. A discourse analysis of some texts of authority political discourse has been chosen as a priority method of analysis for the purpose of revealing the structural components of the power discourse in the city through fixation of the substantive features of the city discursive formations in the political practices of articulation. The following documents have been selected for analysis: official addresses of the mayor (on the occasion of celebrations, problematic situations, public reports, etc.); texts of press releases of local government officials in the city of Dnipro, opposition leaders, active subjects of the political field of the city, published on the official website of the city council and online platforms of local media; posts of key local government officials and opposition leaders (representatives of different political parties) on personal Facebook pages.

The period of the study is from May to October 2019 (time period for the publication of documents for analysis). Total Units of Analysis is 84. One of the groups of documents for the analysis has been selected by the social networking materials of Facebook and understanding the high dynamics of network discourse (constantly changing content), the number of documents that has got into the focus of analysis was deliberately limited (restriction criteria: personalization of post (on behalf of the owner of the page); exclusion of reposts of news resources; election as subjects of discourse that have been analyzed by 1 representative from various political forces represented in local authorities of the city self-government). A structural analysis of each of the documents (type description of the text, main topics, headings, symbolism, concise content) has been carried out in the course of the investigation. The documents have been compared with each other, the social context has been analysed, the typical fragments of discourse have been described and explained.

As a result of the conducted discourse analysis, we propose the following analysis matrix of power discourse in the urban area (see Table 1), which provides attention to the strategies of authority discourse, the grammatology of authority discourse, the intentionality of authority discourse, idioms of authority discourse and the nature of their discourse strategies of the main subjects of authority discourse development in the urban area. The substantive features of the discursive formations of the city in the political practices of articulation in accordance with the above mentioned structural components of authority discourse represent the convergence and diversity increase of positions, the divergence and difference of thoughts, the presence of iconic and ideographic signs, the subject intention of communicants in the middle of discourse, modification and retransmission. It also provides a description of specific discursive acts that are presented in the focus of the analysis. 
Matrix analysis of power discourse in urban area

\begin{tabular}{|c|c|c|}
\hline $\begin{array}{l}\text { Structural } \\
\text { components of } \\
\text { power discourse in } \\
\text { (relative to) city (s) }\end{array}$ & $\begin{array}{l}\text { The substantive features of the } \\
\text { discursive formations of the city in } \\
\text { the political practices of articulation }\end{array}$ & $\begin{array}{l}\text { Characteristic features of } \\
\text { discursive acts }\end{array}$ \\
\hline \multirow[t]{2}{*}{$\begin{array}{l}\text { Strategies of authority } \\
\text { discourse }\end{array}$} & $\begin{array}{l}\text { Convergence and increasing diversity of } \\
\text { positions }\end{array}$ & $\begin{array}{l}\text { duplication of dominant } \\
\text { nomination } \\
\text { classification of objects, } \\
\text { phenomena, processes of } \\
\text { urban area by legitimate and } \\
\text { «loyal» subjects of } \\
\text { discursive } \\
\text { development }\end{array}$ \\
\hline & Divergence and difference of thoughts & $\begin{array}{l}\text { antithesis of nomination and } \\
\text { classification of objects, } \\
\text { phenomena, processes of } \\
\text { urban space by subjects } \\
\text { developing discursive } \\
\text { strategies of «opposition» } \\
\text { status }\end{array}$ \\
\hline $\begin{array}{l}\text { Gramatology of } \\
\text { authority discourse }\end{array}$ & $\begin{array}{l}\text { The presence of iconic and ideographic } \\
\text { signs }\end{array}$ & $\begin{array}{l}\text { semantic-syntagmatic } \\
\text { naturalization of urban } \\
\text { discursive strategies }\end{array}$ \\
\hline $\begin{array}{l}\text { The intentionality of } \\
\text { authority discourse }\end{array}$ & $\begin{array}{l}\text { Subject intension of communicators in } \\
\text { the middle of discourse }\end{array}$ & $\begin{array}{l}\text { modes of (de) legitimation } \\
\text { (outside) of institutional } \\
\text { discursive strategies by } \\
\text { subjects of urban text } \\
\text { development }\end{array}$ \\
\hline $\begin{array}{l}\text { Idioms of authority } \\
\text { discourse }\end{array}$ & Modification and retransmission & $\begin{array}{l}\text { fractality and discretion of } \\
\text { dominant idioms by internal } \\
\text { and external actors in the } \\
\text { development of discursive } \\
\text { strategies for the city }\end{array}$ \\
\hline
\end{tabular}

Our scheme of analysis of the discursive strategies of the political field subjects gives us the opportunity to fix (and at the same time confirms the existence) of the «floating signifiers» described in Laclau and Mouffe theory of discourse. A floating signifiers means elements of discourse open to different meanings and significations. Thus, in the denoted matrix of analysis, among the meaningful features of the discursive formations of the city in the political practices of articulation, there is a divergence and difference of thoughts, which is characterized by the antithetical nomination and classification of objects, phenomena, processes of the urban area by the subjects of development of discursive strategies of «oppositional» status. It is precisely matrix that presents us the presence of «floating signifiers».
For example, in political discourse, the terms «peace», «development», «positive change», «war», «victory», «democracy» can be considered as floating signifiers, since different subjects fill it with different content. The floating signifiers, taken in the context of discourse order, indicates that one discourse has succeeded more than others in fixing a particular meaning of these concepts and that other discourses struggle to win or change this fixation. As a specific case, we will note that, for example, among the subjects of urban political discourse representing political parties «European Solidarity», the «Ukrop» faction in the Dnipro City Council, and in particular in the texts of the mayor (B. Filatov) in the discursive strategy, the nomination of the term «peace» in lexical categories - «victory over enemies», 
«liberation of occupied territories», «Russian aggression», «warrior heroes» and others can be found. At a time when among the discursive strategies of representatives of political parties «Opposition Platform - for Life», «Opposition Bloc», the nomination of the term «peace» is made through lexemes - «negotiations», «compromise», «end of the war», «life preservation», «dialogue» and others. Representatives of the political party «Batkivshchyna» are characterized by more neutral definitions, which in a meaningful sense include both noted options.

Considering the grammatology of authority discourse, we fix the presence of iconic and ideographic signs that present such a characteristic of discursive acts as the semantic-syntagmatic naturalization of urban discursive strategies in the political practices of articulation. These peculiarities of discursive acts are predominantly fixed in the discursive strategies of representatives of official authorities in the city (public and private texts of city mayor and official information of city council). It manifests itself in the presence of such lexical constructions as «outpost city», «this building [Parus Hotel] is a symbol of the city», "the main artery of the city», "space of freedom», «our flag [the highest flagpole in the city] is a symbol independence», «city-defender», "outpost of Ukrainians in the east», "cultural capital», «sports capital», «we always remember our heroes [anti-terrorist operation museum], our city has a memory». That is, the subjects of political discourse actively use the mechanism of ideological, symbolic nomination of specific objects of the architectural landscape of the city or the city as a whole in order to legitimize their own political position, or justify the «correctness» of the strategy of political decision-making.

Thus, as a result of our work, we can state that the modern urban area is a specific way of authority discourse expanding, in particular political. This article focuses specifically on the analysis of political discourse as one of the varieties of power discourse. Since certain characteristics of the power institute indicate such a property, which implies the obligatory implementation by the holders of power of a number of communicative acts, provided that these communicative acts cannot be done by anyone other than the representatives of the power, therefore the attention is actualized just in political perspective. Appealing to the analysis of political discourse in the urban area involved appealing to such categories of analysis as cultural mechanisms of nomination, classification, legitimation and naturalization. A discourse analysis of individual texts of the political discourse of the authorities has been carried out for identification of the structural components of the power discourse in the city by fixing the substantive features of the discursive formations of the city in the political practices of articulation in order to obtain empirical confirmation of the proposed theoretical constructs. The starting point for the implementation of discourse analysis is the theory of discourse analysis by E. Laclau and Ch. Mouffe. The political area of the city of Dnipro has been chosen as a specific case. As a result, a possible variant of the matrix of power discourse analysis in the urban area, which involves attention to the strategies of authority discourse, the grammatology of authority discourse, idioms of authority discourse, and the nature of their projection in the discursive strategies of development in urban area is suggested. It is further appropriate to analyze the discursive strategies of the official / opposition political force in the political sphere of the city more closely and to compare the nature of the discourse of official classic media and social networks.

\section{REFERENCES}

1. Lefebvre, A. (2015). Production of space. Moskva: "Strelka Press " [in Russian].

2. Chernyavskaya, V. (2006). Discourse of power and power of discourse. Problems of speech influence. Mokva: Flinta [in Russian].

3. Shapochkin, D. (2013). The discourse of power: the linguocultural aspect. Vestnik Tomskogo gosudarstvennogo universiteta - Bulletin of the Tomsk State University, 10, 117-122 [in Russian].

4. Karasik, V. (2000). On types of discourse. Linguistic personality: institutional and personal discourse Volgograd: Peremena [in Russian]

5. Perskova, Y. (2015). Discourse as a manifestation of social interaction: the parameter of power. Naukovyi visnyk Mizhnarodnoho humanitarnoho universytetu - Scientific Bulletin of the International Humanities University. Ser .: Philology, 16, 186-189 [in Ukrainian]. 
6. Poda, T. (2015). Discourse of Power and Power Relations in Postmodernity: Socio-Philosophical Aspect. Visnyk NAU. Seriia: Filosofiia. Kulturolohiia - Bulletin of NAU. Series: Philosophy. Cultural Studies, 1(21), 64-67 [in Ukrainian].

7. Soghomonyan, V. (2012). What is a discourse of power? «21-j VEK»- «21st century», 1(21), 34-51 [in Russian]. 8. Kusko, K (2001). Discourse of foreign language communication. K. Kusko (Ed.). Lviv: View of Lviv. nat. Ivan Franko University [in Ukrainian].

9. Medvid, O. (2008). Pragmatic interpretations of texts of political discourse. Visn. SumDU - Visn. SSU, 1, 66-71 [in Ukrainian].

10. Kadlubovich, T. (2010). The relation between the concepts of political discourse and political communication. Visnyk Natsionalnoi akademii derzhavnoho upravlinnia - Bulletin of the National Academy of Public Administration, 1, 192-199 [in Ukrainian].

11. Akinchitz, N. (2007). Political discourse as an object of scientific analysis. Kultura narodov PrichernomoryaCulture of the peoples of the Black Sea, 107, 72-76 [in Ukrainian].

12. Bourdieu, P. (1994). Social space and symbolic power. Beginnings. (N. Shmatko, Trans.). Moskva: Socio-Logos [in Russian].

13. Berger, P., \& Luckman, T. (1995). Social construction of reality. Moskva : Medium [in Russian].

14. Soroka, Y. (2017). Naturalization by J. Butler in the perspective of the concept of cultural mechanisms of power. Aktualni problemy sotsiolohii, psykholohii, pedahohiky - Actual problems of sociology, psychology, pedagogy, 2(33), 14-27 [in Ukrainian].

15. Kryvenko, S. (2012). The Semantics of Political Discourse. Visnyk NTUU «KPI»Politolohiia. Sotsiolohiia. Pravo - Bulletin of NTUU «KPI». Politology. Sociology. Right, 1(13), 28-32 [in Ukrainian].

16. Chalaby, J. K. (1996). Beyond the prison-house of language: Discourse as a sociological concept. British Journal of Sociology, 47, 684-698.

17. Boyko, O. (2017). Discourse as a tool of social power. Visnyk Cherkaskoho universytetu - Bulletin of Cherkasy University, 1, 83-88 [in Ukrainian].

18. Rusakova, O. (2006). The main varieties of modern theories of political discourse: the experience of classifications. Polytex, 3, 191-213 [in Russian].

\section{Міхно Надія Костянтинівна}

Кандидат соціологічних наук, доцент Дніпровський національний ім. Олеся Гончара 49010, Дніпро, просп. Гагаріна, 72

Email: krupskayanadiya@gmail.com

\section{Mikhno Nadiya}

Ph.D. of Sociological Sciences, Assoc. Prof.

університет Oles Honchar Dnipro National University

72, Gagarin Ave., Dnipro, 49010, Ukraine

ORCID: 0000-0001-8120-7182

Цитування: Міхно Н. К. Виробництво дискурсивних стратегій влади в політичному просторі м. Дніпро. Науково-теоретичний альманах «Грані». 2020. Т. 23, № 4. С.36-44.

Citation: Mikhno, N. K. (2020). Vyrobnytstvo dyskursyvnykh stratehii vlady v politychnomu prostori $\mathrm{m}$. Dnipro [Development of discurcive power strategies in political space of Dnipro]. Scientific and theoretical almanac «Grani», 23 (4), 36-44.

Стаття надійшла / Article arrived: 04.03.2020 